\title{
Evaluation of Environmental and Ecological Effects Due to the Accident in an Oil Pipe from Petrobras in Guanabara Bay, RJ, Brazil
}

\author{
Patrícia P. B. Eichler ${ }^{1}$, Beatriz Beck Eichler², Felipe Mendonça Pimenta ${ }^{3}$, \\ Evelyn da Rocha Mendes Pereira ${ }^{2}$, Helenice Vital ${ }^{1}$ \\ ${ }^{1}$ Programa de Pós Graduação em Geofísica e Geodinâmica (PPGG), Laboratório de Geologia e Geofísica \\ Marinha e Monitoramento Ambiental, Centro de Ciências Exatas e da Terra da Universidade Federal do Rio \\ Grande do Norte (GGEMMA, CCET, UFRN, Brazil), Natal, Brazil \\ ${ }^{2}$ Instituto Oceanográfico, Universidade de São Paulo (USP), São Paulo, Brazil \\ ${ }^{3}$ Centro de Filosofia e Ciências Humanas, Universidade Federal de Santa Catarina, Florianópolis, Brazil \\ Email: ${ }^{*}$ patriciaeichler@gmail.com
}

Received 1 July 2014; revised 19 August 2014; accepted 3 September 2014

Copyright (C) 2014 by authors and Scientific Research Publishing Inc.

This work is licensed under the Creative Commons Attribution International License (CC BY). http://creativecommons.org/licenses/by/4.0/

(c) (i) Open Access

\begin{abstract}
We aim to evaluate the quality of the Guanabara Bay sediments and the ecological changes due to the PETROBRAS crude oil leak in January 2000. Twenty-six sediment samples collected in July 2000 and in February 2001 were analyzed for $\mathbf{p H}$, dissolved oxygen, and foraminiferal composition. In the northwest and central parts of the bay, low oxygen dissolved values are related to waste discharges with the dominance of Buliminella elegantissima. In winter, near Iguaçu River, the $\mathrm{pH}$ of the sediment is low, therefore highly acidic. The acidity is responsible for the foraminiferal low diversity limiting the occurrence of species with fragile tests. On the other hand, thicker tests of Elphidium spp. disappeared last, therefore increasing its relative dominance in winter. In summer, this is a barren zone. The explanation lies in the continuous dissolution of tests that culminated with the total disappearance of these microorganisms one year after the accident.
\end{abstract}

\section{Keywords}

Foraminifera, pH, Oxygen Concentration, Guanabara Bay, Environmental Quality

\section{Introduction}

The use of an easy-handle and inexpensive biological indicator (benthic foraminifera) is a good alternative for

"Corresponding author.

How to cite this paper: Eichler, P.P.B., et al. (2014) Evaluation of Environmental and Ecological Effects Due to the Accident in an Oil Pipe from Petrobras in Guanabara Bay, RJ, Brazil. Open Journal of Marine Science, 4, 298-315.

http://dx.doi.org/10.4236/ojms.2014.44027 
environmental studies. They are able to summarize the general characteristics of the environment (oceanographic and geological), highlight environmental variations over short periods of time, and react sensitively to seasonal changes and to anthropogenic effects.

The great advantage of using foraminifera lies in their being abundant and easily collected. Some features like the large number of specimens, the specific composition of associations, diversity and dominance, and the number of planktonic forms present, are useful for the recognition of different sub-environments [1]. Moreover, the composition of the shell (fully organic material bonded or not selected, limestone tiles, hyaline or silica), provides information on the environment [2]. Characteristics of the shell, such as thickness of the chambers, size and strain can also provide information about the prevailing conditions of temperature, salinity, food availability, pollution by hydrocarbons and heavy metals. The number of planktonic forms and porcelain found in estuarine environments may also indicate the proximity or penetration of ocean currents [3]. The study of foraminifera in polluted or contaminated water is important for its practical significance, which can be used through the establishment of indicator species. Some species may respond favorably to pollution and become dominant in contaminated areas while others may react negatively, decreasing in size, or become absent [4]. The usual response of benthic foraminifera is a decrease in diversity with a concomitant increase (of pollution) until only one single opportunistic species remains [5].

This paper focuses on the study of foraminiferal species correlated with chemical effects related to the oil spill in the pipeline PE-II (PETROBRAS) from Duque de Caxias (REDUC). On January $18^{\text {th }}, 2000,1292 \mathrm{~m}^{3}$ of fuel oil type MF380 leaked out into the waters of the Guanabara Bay. The accident was one of many oil spills occurring in the country in recent years. The accident happened in the north of the Ilha do Governador (Figure 1). The oil slick extended over a range greater than $50 \mathrm{Km}^{2}$, reaching part of the wetland protected area of Guapimirim mangrove, and beaches of Guanabara Bay, causing serious damage to the social order and severe costs to the local population. The communities that directly or indirectly drew their livelihood from the waters of Gua-

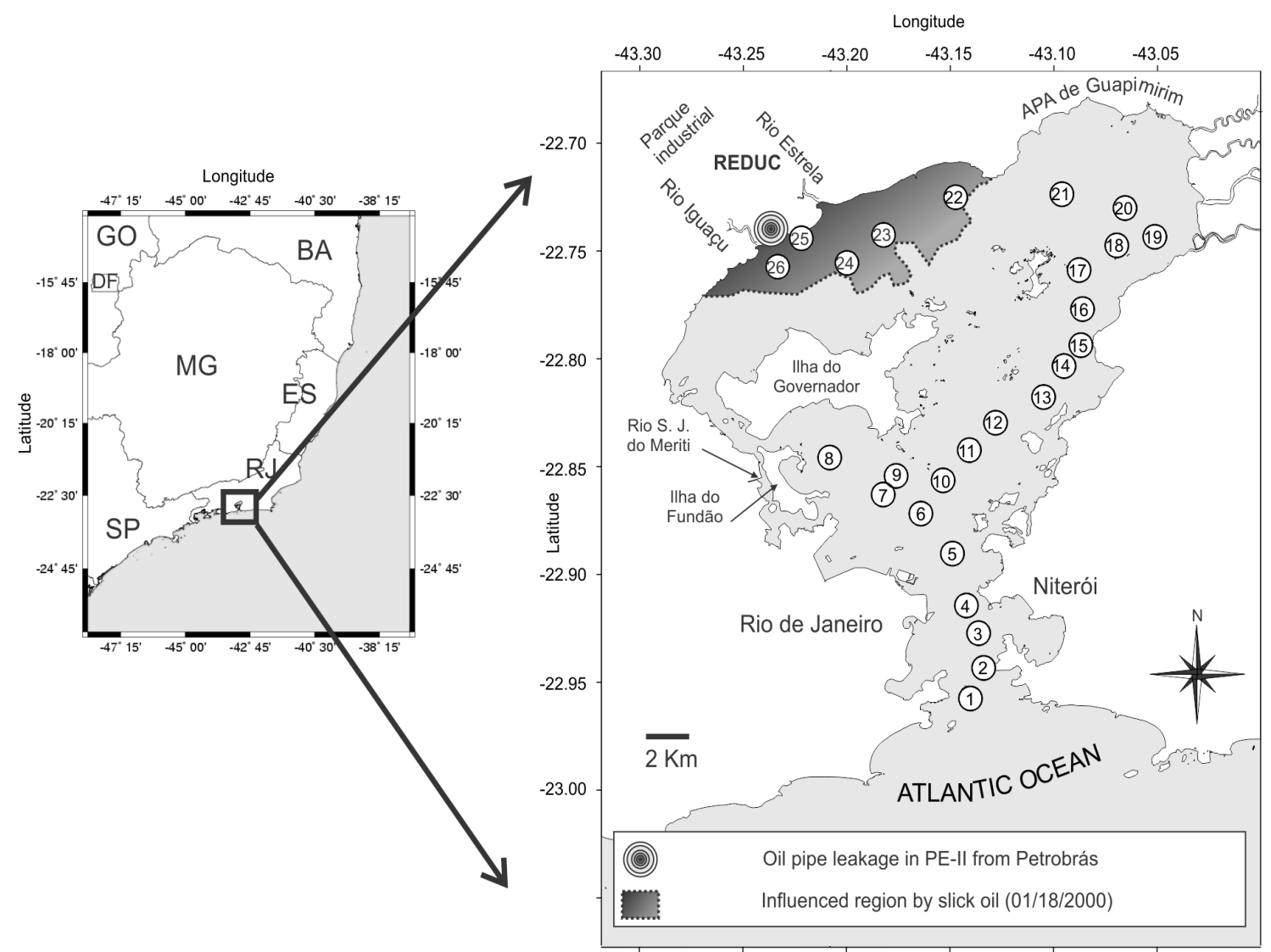

Figure 1. A map of Guanabara Bay, the region of the accident in the oil pipe PE-II (Petrobras). Sample points collected in winter 2000 and summer 2001. The area affected for the spill is indicated as the dark shaded area near REDUC. 
nabara Bay, such as fishing and tourism, were even more damaged by the death of fish and shellfish caused by contamination and lack of oxygen.

In general, an oil spill alters the oil's chemical composition because it allows the breakdown of oil components. The oil spill releases $\mathrm{H}_{2} \mathrm{~S}$ (hydrogen sulfide), ammonia and methane, causing the decrease in $\mathrm{pH}$ of the sediment [6] and the decrease in the dissolved oxygen concentration in the water. These changes interfere with the natural environment of the affected region, making it unstable.

In order to assess the environmental quality of the region and the damage to the marine ecosystem that occurred due to the oil leak, we collected sediment and water samples in two seasons, winter 2000 (6 months after the accident) and summer 2001 (1 year after the accident). We aimed to evaluate the response of foraminifera and chemical data ( $\mathrm{pH}$ and oxygen) in the face of anthropogenic change.

\section{Study Area}

Guanabara Bay is located in the state of Rio de Janeiro, Brazil, between $22^{\circ} 41^{\prime}-22^{\circ} 58^{\prime} \mathrm{S}$ and $43^{\circ} 02^{\prime}-43^{\circ} 18^{\prime} \mathrm{W}$. The region originated in the sea drowning of a Pleistocene river basin, and is surrounded by coastal mountain ranges, escarpments of the Serra do Mar (Serra dos Órgãos), isolated hills grouped in small clusters, and the Baixada Fluminense.

The climate is tropical, hot and humid, the average temperatures vary between $22^{\circ} \mathrm{C}$ and $26^{\circ} \mathrm{C}$ with average daily high in summer $\left(30^{\circ} \mathrm{C}\right.$ to $\left.32^{\circ} \mathrm{C}\right)$, rainfall varies from 1200 to $1800 \mathrm{~mm}$ per year [7]. In the four months of the so-called high summer (December-March) "the very hot days" are followed by heavy and rapid rains. The average rainfall in Guanabara Bay does not oscillate much, but in the year 2000, the difference between the dry and rainy season was significant (Figure 2).

The sedimentation rates in Guanabara Bay have increased overlapping geological or natural siltation. Bottom sediments are dominated by silted sand and mud. Currently, the straightening and channeling of rivers and destruction of mangroves increases the volume of sand loads [8]. The grain size distribution reflects the tidal current energy near the bottom, which is directly influenced by bottom morphology and the Guanabara Bay shoreline contour. The bottom sediment of the bay ranges from clay to coarse sand and sedimentary textures can be comprised of from $0 \%$ to $100 \%$ of sand, $0 \%$ to $92 \%$ silt and $0 \%$ to $85 \%$ of clay. The samples from Guanabara Bay were classified into four principal groups: clay, sand, clayey silt and clay-silt-sandy, by its median [8]. The strong production of organic mud is related to the eutrophication of the Bay related to the sewage and garbage. Therefore the increase in the amount of sand and mud deposited explains the high levels of siltation of the bay.

There are 45 rivers flowing into the Guanabara Bay that work as drainage channels, the largest of which has its source in the Serra do Mar. Among the rivers that flow into the region, Iguaçú, Estrela, Guapimirim, Guaraí River, Macacu River and Guaxindiba River are the largest ones.

The deeper sites are found in the deeper navigation channel. The average depth of the Guanabara Bay is $7.6 \mathrm{~m}$; and $3 \mathrm{~m}$ in the northeast of the Bay, $8.3 \mathrm{~m}$ in the region between the Governors Island and the tips of the Calabouço and Gragoatá and $16.9 \mathrm{~m}$ in the outer portion of the bay [7].

The circulation and salinity of the Bay waters are subject to tidal movements, wind and river discharge. The Guanabara Bay is the largest coastal bay in Brazil [9], and this region fits the model proposed by [10], as a salt wedge estuary.

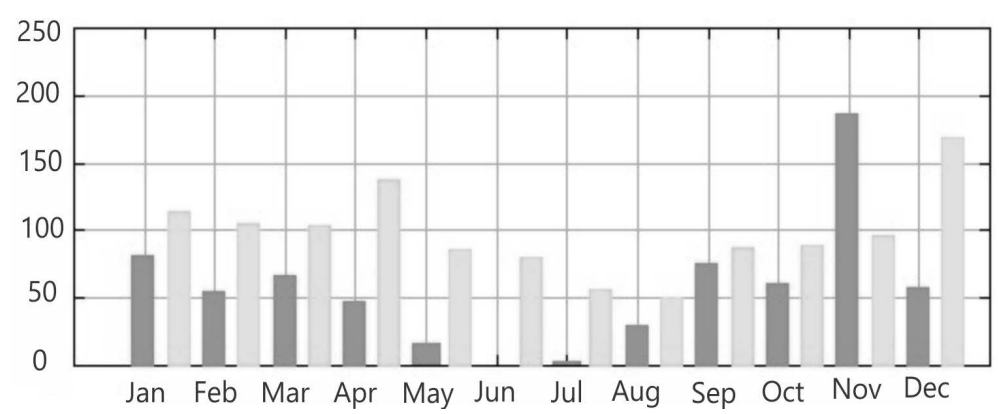

Figure 2. The average rainfall in the region of the Guanabara Bay. Dark gray, rainfall (mm) in Rio de Janeiro in 2000, and light gray, rainfall in Rio de Janeiro for the period of 1961-1990 (NMT, 2004). 
The highest salinities occur in the entrance to the Bay, and the less saline waters occur near the mouths of rivers and wetlands in the northern portion of the Bay, reaching salinity values below 8. In the intermediate and south portions of the Bay, salinity ranges between 30 and 34 [11] [12].

Daily, this region receives a large amount of industrial and municipal waste, mostly untreated. The dumping of sewage from the city of Rio de Janeiro takes place mainly in the waters of the S. J. Meriti, a river located in the west of Ilha do Governador.

More than 6000 industries, 2 commercial ports, 16 marine terminals, 2 naval bases, a shipyard and a large number of ferries, fishing boats and yachts, and the largest oil refinery in Brazil, Duque de Caxias (REDUC) pour in the waters, 1.4 tons of oil per day [13] and industrial waste, into Guanabara Bay.

\section{Methods}

\subsection{Sampling}

The collection of bottom sediment and hydrologic variable measurements (concentration of oxygen in the surface and bottom) were carried out in the periods of 6th to 17th of July 2000 (winter), and 1st to 15th of February 2001 (summer) in 26 stations (Figure 1). The sediment sampling was carried out with a Petersen Grab sampler. Samples were collected from the interface sediment-water for analysis of foraminiferal species. Sampling stations and the location of the area affected by the spill are shown in Figure 1. Sampling began at the entrance of the bay, towards the middle part and finally at the northern part of the bay.

\subsection{Chemical Variables}

The dissolved oxygen concentration of water was measured with an oximeter Metler Toledo, and for $\mathrm{pH}$ measurements, the electrodes were coupled to an Eydan portable analyzer, model pH 91. Both measurements were performed in situ.

\subsection{Biological Variables}

The collection of sediment for analysis of biological material was performed at 26 points in the winter and repeated in the summer, totaling 52 samples. For the analysis of microfauna, the top layer (five centimeters) was removed from the sediment collected, and placed in vials with Bengal Rose $(1 \mathrm{~g} / 1000 \mathrm{ml}$ etilic alcohol). Bengal Rose stains the protoplasm of organisms alive at the time of collection, while the role of the alcohol is to prevent bacterial attack. The sediment containing the foraminifers (50 cc) was washed in two successive sieves of 0.500 $\mathrm{mm}$ and $0.062 \mathrm{~mm}$ and then dried. The samples were separated by flotation in carbon tetrachloride. After this, the foraminifera were identified at species taxonomic level. The determination of species was done using a binocular stereoscope. Specimens were counted to a maximum of 500. After that number, the sample was divided using a splitter (Geological Green). Foraminifera were counted in one portion and multiplied by the number of fractions which the sample was divided into, obtaining the average absolute frequency of specimens sampled per station.

- AE-index

To assess the degree of hypoxia in the Bay, we used the ecological AE index to measure hypoxia $\left(\mathrm{O}_{2}<2 \mathrm{mg} / \mathrm{l}\right)$ related to coastal eutrophication [14]. This index takes into account the absolute frequency of Elphidium spp., Ammonia tepida and A. parkinsoniana (morphological variations of Ammonia beccarii). Ammonia spp. is abundant in polluted sediments rich in organic matter while specimens of Elphidium spp. are not often found in such environments.

The $\mathrm{AE}$ index follows the formula below:

$$
\mathrm{AB} \text { Ammonia/( } \mathrm{AB} \text { Ammonia }+\mathrm{AB} \text { Elphidium }) \times 100
$$

where $\mathrm{AB}=$ absolute frequency (number of specimens $/ 50 \mathrm{~cm}^{3}$ ).

The AE index is affected by seasonal hypoxia produced by "blooms" of phytoplankton and it is important to infer measures related to the eutrophication of the environment.

\subsection{Analysis of Data}

From the absolute frequency, we calculated the relative frequency of species of foraminifera in the study area. 
The data on main foraminiferal relative frequency and $\mathrm{AE}$ index of environmental hypoxia was used to generate the contour maps to better visualize patterns. The contour maps (Figures 3-8) were calculated by Surfer 9 from the digitization of nautical chart n. 1501.

The interpretation was based on the kriging technique, using the program Surfer for Windows, which according to [15] is a statistical technique used to estimate the values of variables distributed in space, with the possible identification of spots when the levels in the different parameters are very disparate. It is known that the kriging technique has been used in studies of geology to estimate the distribution of variables in patches of marine sediments [16]. This methodology was also applied to the chemical variables (oxygen and $\mathrm{pH}$ ) measured at the time of collection.

\section{Results}

\subsection{Chemical Variables}

The positioning of the stations, the $\mathrm{pH}$ of the sediment and dissolved oxygen concentration in surface and bottom water, obtained at the time of sampling in winter and summer, can be seen in Table 1 . Data from this table were contoured in maps to provide a better view of the chemical parameters measured simultaneously with the collection of bottom sediment.

Figure 3 shows that in winter, the $\mathrm{pH}$ values for the northwest region are lower (stations 17 to 26), when compared to other locations (stations 1 - 16). At station 26, near the Duque de Caxias (REDUC) oil refinery, there is the lowest $\mathrm{pH}$ value among samples, indicating the highest acidity of the sediment collected (pH 1.81). In the summer, there was an increase of $\mathrm{pH}$ in every area.

Regarding the oxygen concentration in both winter and summer, it was observed that higher concentration is found in surface water and the lowest values in bottom waters (Figure 4).

In winter, the entrance of the bay and the central regions are the more oxygenated environments. In general, the less oxygenated sites are located in the northeastern part of the bay, near the Guapimirim APA, and in the northwest, near the REDUC. During this period, the oxygen content near the surface nearby REDUC are very low, potentially indicating that the oil spill and chemical processes involved consumed the oxygen in the water.
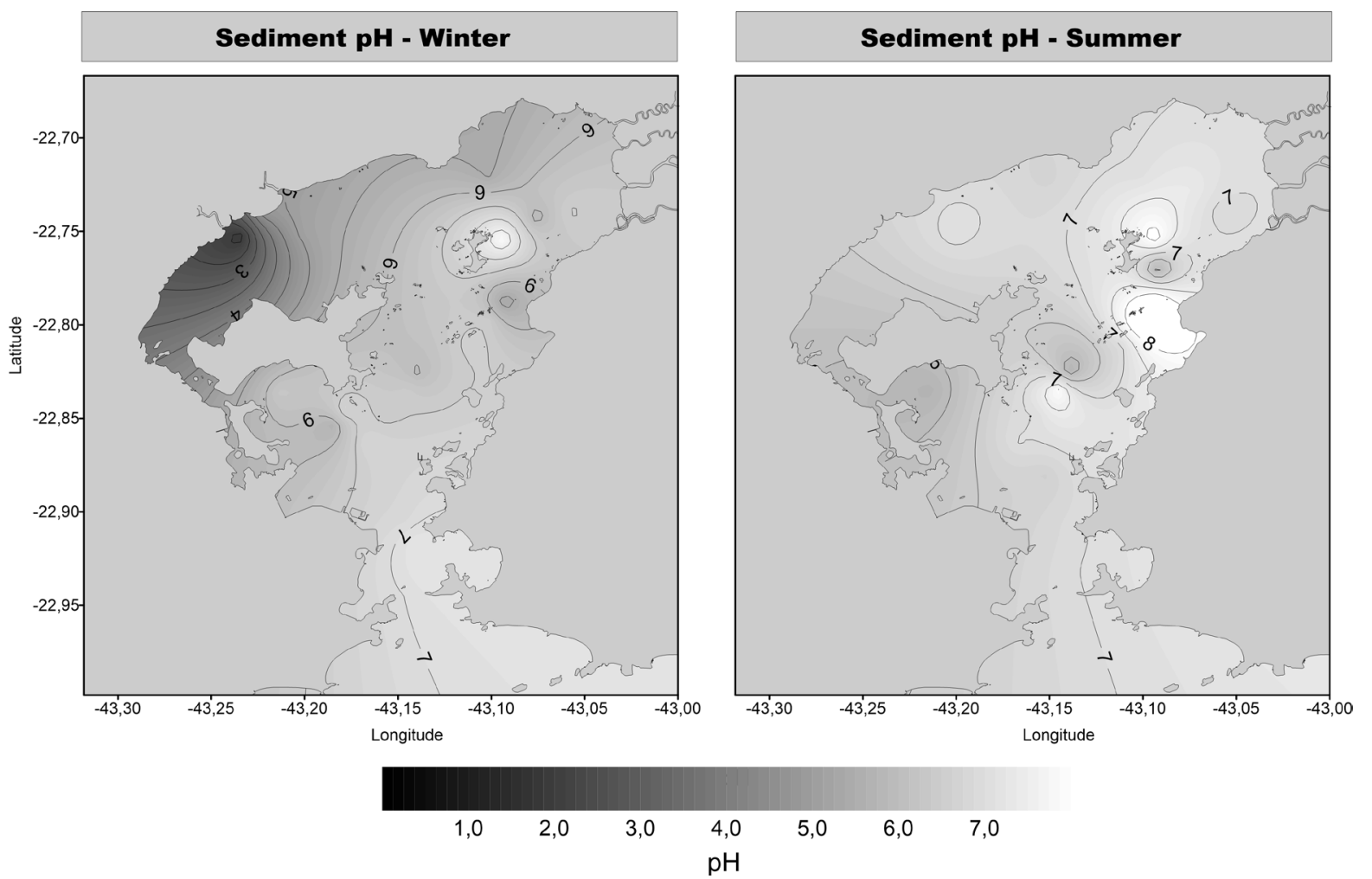

Figure 3. The distribution of $\mathrm{pH}$ at the collection stations during summer and winter. 

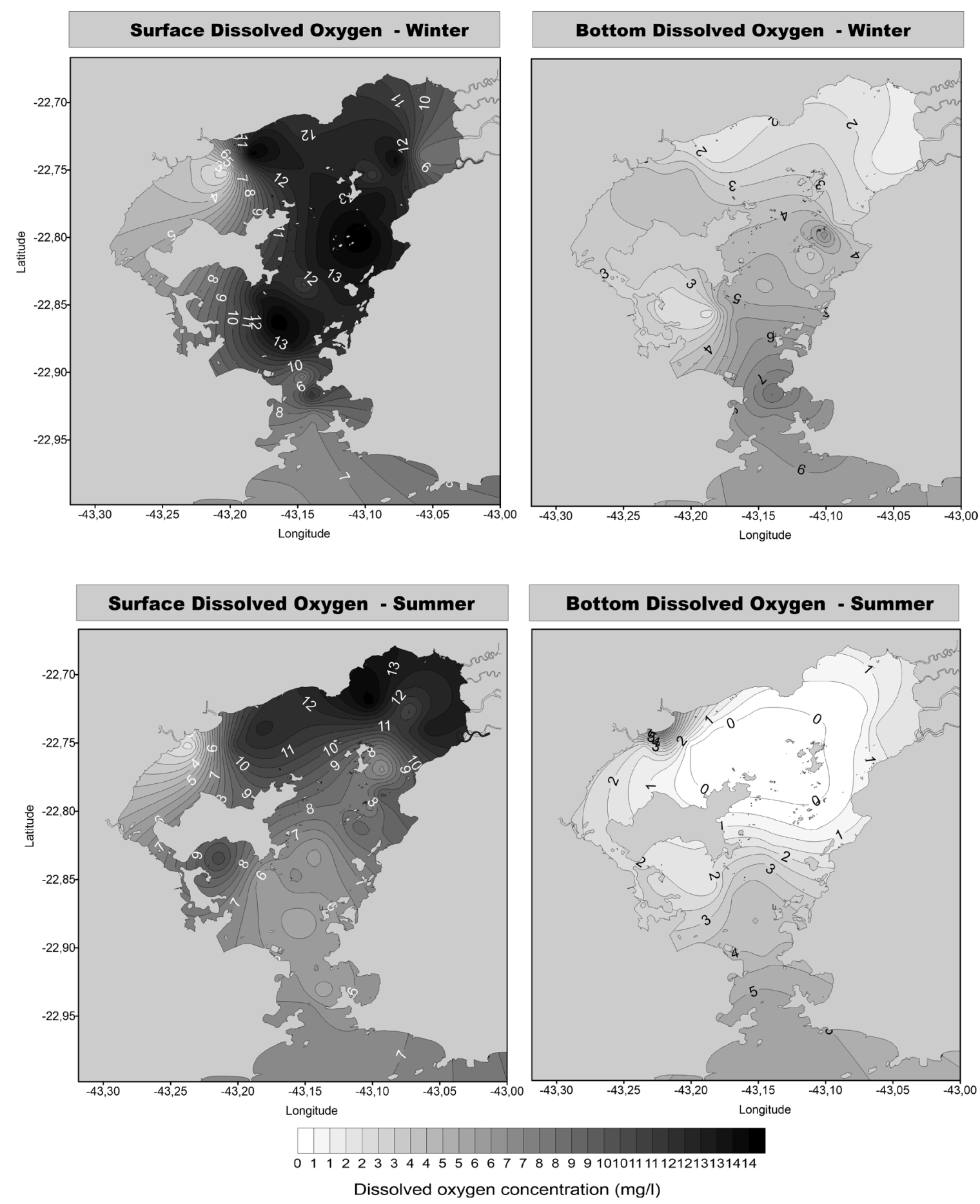

Figure 4. The distribution of oxygen concentration at the collection stations during summer and winter.

Still, with respect to the northwestern part of the Bay, the low surface oxygen content in the Iguaçu River is related to existing discharges of pollutants. In summer, bottom oxygen in stations 12 to 24 in the central and northeastern Bay were very low (between 0.12 and 0.3) showing the presence of an anoxic zone in this region.

\subsection{Biological Parameters}

The number of specimens observed during the winter was higher than the number of specimens observed in 


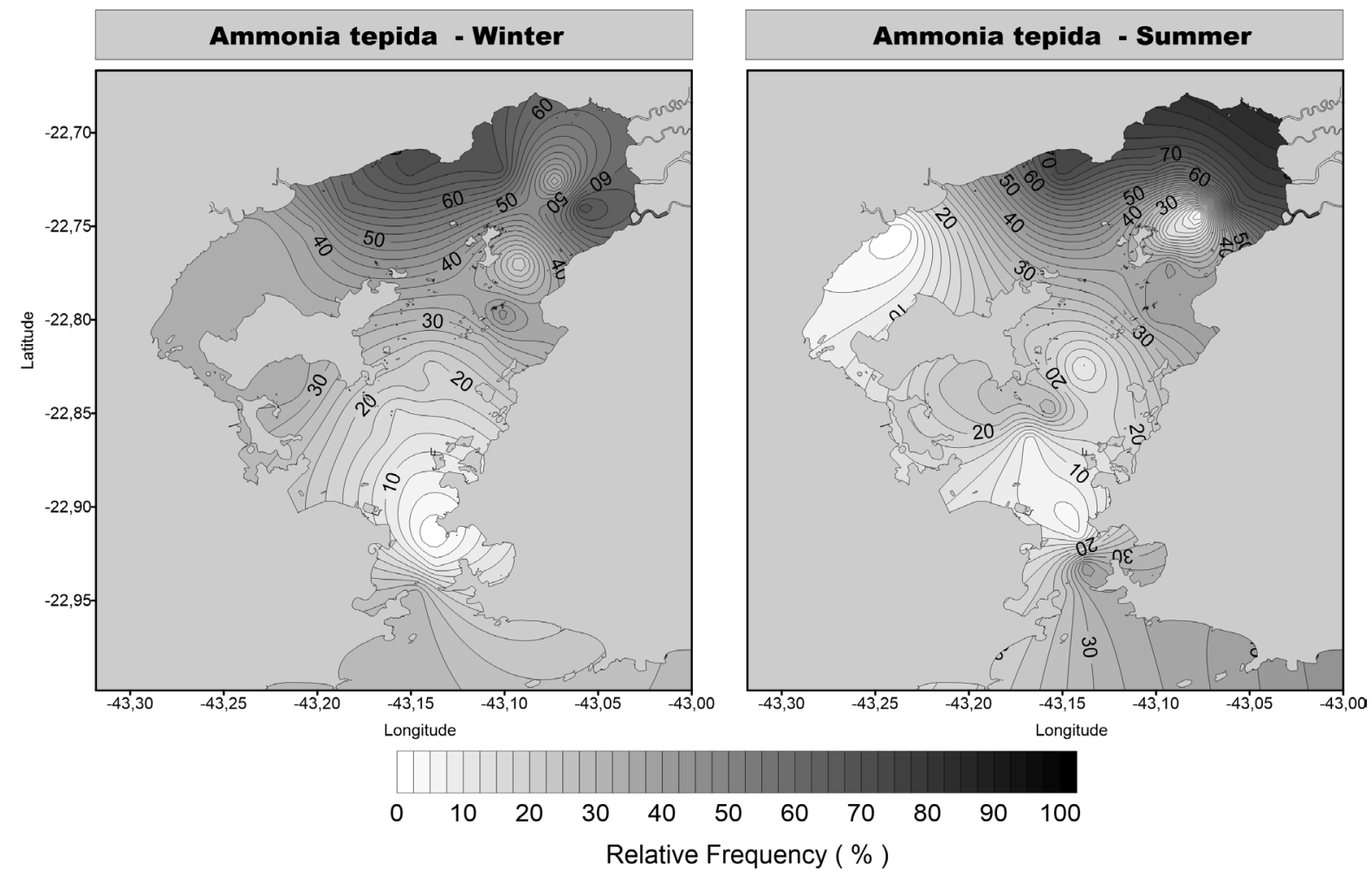

Figure 5. Distribution of the relative frequency of Ammonia tepida.

Table 1. Geographical positions, sediment pH and oxygen concentration (surface and bottom) in winter and summer.

\begin{tabular}{|c|c|c|c|c|c|c|c|}
\hline Stations & Geographical & pH & $\mathrm{O}_{2}$ Surface $\mathrm{g} / \mathrm{ml}$ & $\mathrm{O}_{2}$ Bottom g/ml & pH & $\mathrm{O}_{2}$ Surface $\mathbf{g} / \mathrm{ml}$ & $\mathrm{O}_{2}$ Bottom g/ml \\
\hline & Position & Winter & Winter & Winter & Summer & Summer & Summer \\
\hline 1 & $22^{\circ} 56^{\prime} 68^{\prime \prime}-43^{\circ} 50^{\prime} 88^{\prime \prime}$ & 7 & 7.01 & 6.09 & 7 & 6.86 & 5.5 \\
\hline 2 & $22^{\circ} 55^{\prime} 90^{\prime \prime}-43^{\circ} 08^{\prime} 29^{\prime \prime}$ & 7.21 & 7 & 6.3 & 6.98 & 5.07 & 4.98 \\
\hline 3 & $22^{\circ} 54^{\prime} 97^{\prime \prime}-43^{\circ} 08^{\prime} 43^{\prime \prime}$ & 7.22 & 11.7 & 8.1 & 6.92 & 6.06 & 4.68 \\
\hline 4 & $22^{\circ} 54^{\prime} 23^{\prime \prime}-43^{\circ} 08^{\prime} 77^{\prime \prime}$ & 6.84 & 7.4 & 7.1 & 6.85 & 5.84 & 3.82 \\
\hline 5 & $22^{\circ} 52^{\prime} 84^{\prime \prime}-43^{\circ} 09^{\prime} 16^{\prime \prime}$ & 6.7 & 13.4 & 6.1 & 6.6 & 5.12 & 4.03 \\
\hline 6 & $22^{\circ} 51^{\prime} 77^{\prime \prime}-43^{\circ} 10^{\prime} 04^{\prime \prime}$ & 6.75 & 14.5 & 5.6 & 7.02 & 5.72 & 3.71 \\
\hline 7 & $22^{\circ} 51^{\prime} 26^{\prime \prime}-43^{\circ} 11^{\prime} 09^{\prime \prime}$ & 5.66 & 11 & 1.6 & 6.6 & 5.8 & 1.45 \\
\hline 8 & $22^{\circ} 50^{\prime} 88^{\prime \prime}-43^{\circ} 11^{\prime} 77^{\prime \prime}$ & 6.3 & 8.07 & 2.51 & 5.7 & 10.5 & 1.83 \\
\hline 9 & $22^{\circ} 50^{\prime} 76^{\prime \prime}-43^{\circ} 10^{\prime} 73^{\prime \prime}$ & 6.68 & 13 & 5 & 6.72 & 5.63 & 2.45 \\
\hline 10 & $22^{\circ} 50^{\prime} 88^{\prime \prime}-43^{\circ} 09^{\prime} 42^{\prime \prime}$ & 6.39 & 13 & 5 & 7.02 & 6.8 & 3.4 \\
\hline 11 & $22^{\circ} 50^{\prime} 07^{\prime \prime}-43^{\circ} 08^{\prime} 69^{\prime \prime}$ & 6.42 & 10.6 & 4.2 & 8.06 & 5.75 & 2.83 \\
\hline 12 & $22^{\circ} 49^{\prime} 52^{\prime \prime}-43^{\circ} 08^{\prime} 37^{\prime \prime}$ & 5.94 & 12.76 & 4.99 & 5.7 & 6.09 & 1.46 \\
\hline 13 & $22^{\circ} 48^{\prime} 65^{\prime \prime}-43^{\circ} 06^{\prime} 62^{\prime \prime}$ & 6.6 & 14 & 3.2 & 7.02 & 8.93 & 0.31 \\
\hline 14 & $22^{\circ} 47^{\prime} 82^{\prime \prime}-43^{\circ} 06^{\prime} 05^{\prime \prime}$ & 6.42 & 14.6 & 6.7 & 8.88 & 7.15 & 0.13 \\
\hline 15 & $22^{\circ} 47^{\prime} 26^{\prime \prime}-43^{\circ} 05^{\prime} 58^{\prime \prime}$ & 6.25 & 13 & 2.7 & 8.72 & 9.82 & 0.09 \\
\hline 16 & $22^{\circ} 46^{\prime} 96^{\prime \prime}-43^{\circ} 05^{\prime} 71^{\prime \prime}$ & 6.5 & 13.52 & 2.8 & 5.7 & 6.1 & 0.12 \\
\hline
\end{tabular}




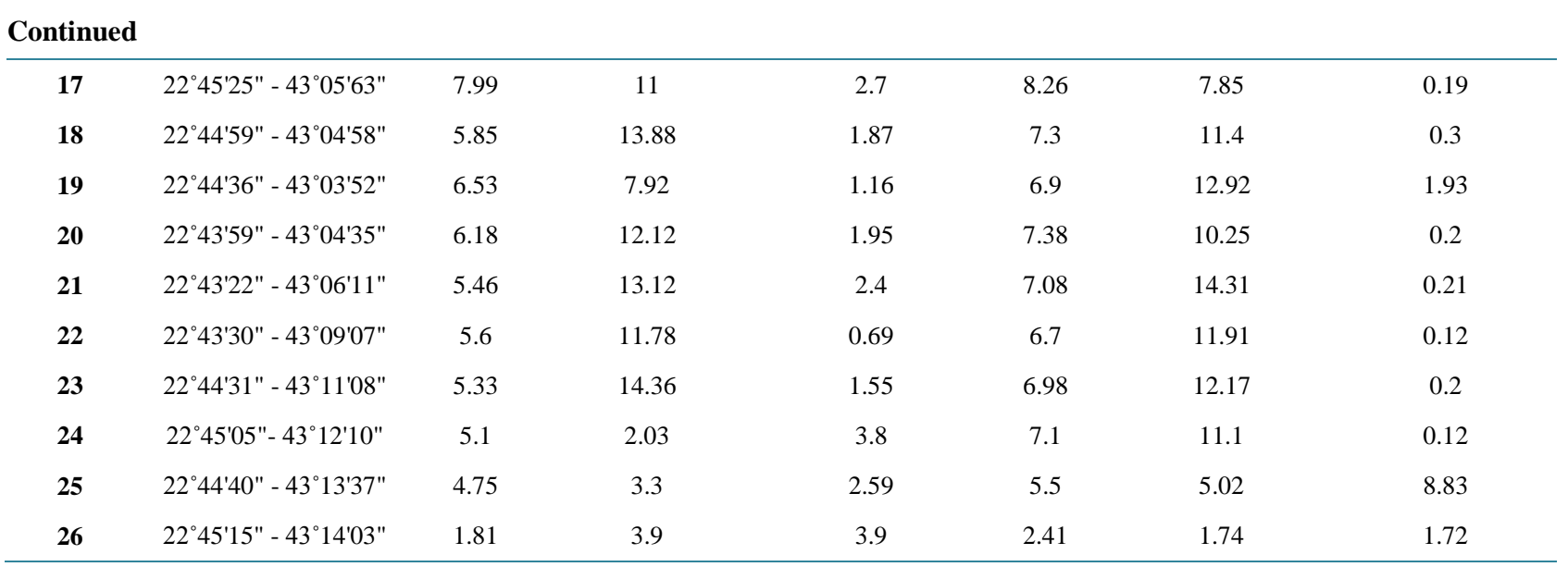

summer. In the winter, 295,113 specimens were found and in summer, 116,241 specimens were found. These specimens are distributed in 51 species of foraminifera belonging to the suborders Rotaliina (vast majority), Textulariina and Miliolina. The main species found in winter were Ammonia tepida, Bolivina striatula, Bulimmina elongata, Buliminella elegantissima, Cassidulina subglobosa, and Quinqueloculina seminulum and in the summer, the dominant species were also A. tepida, B. striatula and B. elegantissima. Both in winter (Table 2) and summer (Table 3), the highest total relative frequencies were found at stations 6, 7, 8, 9, located in the south of Ilha do Governador, 13 and 14 located in the central portion of the Bay and at station 22, which is located in the northeast portion.

The most frequent species found in these regions belong to the suborder Rotaliina, Ammonia tepida, Bolivina striatula, Buliminella elegantissima, Fursenkoina pontoni, and Bulimmina elongata. Specimens of suborder Textulariina (Gaudryina exillis) were found in a lower percentage and concentrated only in the middle part of the bay. In winter, the species Quinqueloculina seminulum (Miliolina) was fairly representative in the northern regions of the Bay.

Contour maps of relative frequency of the main species of foraminifera show that calcareous hyaline species Ammonia tepida was dominant at almost all stations, indicating its cosmopolitan characteristic (Figure 5). However, note that the highest relative abundance of this species occurs in the north and northeast of the Bay, near the APA Guapimirim. In summer, one year after the accident, there is the absence of this species near the site of the oil spill, especially in station 26. The shells of calcium carbonate $\left(\mathrm{CaCO}_{3}\right)$ were dissolved due to the increased acidity of the sediment. This acidity which began during the oil spill continues gradually dissolving shells, demonstrating ecological effects after the accident.

The species belonging to the genus Elphidium are mixohaline, characteristic of environments with lower salinity. In Figure 6, we observe the occurrence of this species in stations 22 to 26, where there is greater influence of river drainage. This genus had a high relative abundance in the REDUC region only in winter, while in summer; the region was a barren zone.

In winter, station 26, near REDUC presents very acidic $\mathrm{pH}$ of the sediment. This acidity negatively influences the diversity of species, limiting the occurrence of species with thinner shells and thereby increasing the relative dominance of Elphidium spp. This was the only sterile station in the summer. This fact can be explained by the continuous dissolution of these shells; being thicker, they are the last ones to dissolve, culminating in the total disappearance of these organisms one year after the accident.

\subsection{Statistical Indices}

Through the AE index, we can verify that in the summer, compared with data obtained in winter, there was an increase of hypoxia due to decreased oxygen concentration in all environments (Table 4). In winter, highest values of this index were observed closer to the margin of the Bay indicating high productivity related to hypoxia and eutrophication. Hypoxia has been found especially in the central regions.

In summer, the southern and central portions of the Ilha do Governador, near the São J. do Meriti, have higher values indicating high environmental hypoxia. These data corroborate oxygen concentration of an anoxic zone in this region. 
Table 2. Relative frequency of species distribution in Guanabara Bay (winter).

\begin{tabular}{|c|c|c|c|c|c|c|c|c|c|c|c|c|c|c|c|c|c|c|c|c|c|c|c|c|c|c|}
\hline WINTER & 1 & 2 & 3 & 4 & 5 & 6 & 7 & 8 & 9 & 10 & 11 & 12 & 13 & 14 & 15 & 16 & 17 & 18 & 19 & 20 & 21 & 22 & 23 & 24 & 25 & 26 \\
\hline Ammobaculites sp. & 0.2 & & 5.2 & & & 4.2 & & 2.3 & & & 4.0 & & 0.7 & & & 0.6 & & & & & & & & & & \\
\hline Ammonia tepida & 7.12 & 29.2 & & 3.8 & 8.31 & 16.8 & 20.8 & 35.0 & 20.6 & 14.7 & 21.8 & 18.3 & 28.5 & 45.1 & 33.41 & 18.63 & 35.5 & 51.7 & 70.13 & 31.36 & $68.9^{\circ}$ & 70.75 & 59.44 & 40.03 & 38.3 & 32.9 \\
\hline Ammotium salsum & 0.5 & & & & & 0.3 & 0.7 & 0.2 & & 1.4 & 7.3 & & 1.4 & & & 0.3 & & & & & & & & & 0.6 & \\
\hline Amphistegina scalaris & & & & & & & & & & 0.5 & 0.8 & & & & & & & & & & & & & & & \\
\hline $\begin{array}{l}\text { Arenoparrella } \\
\text { mexicana }\end{array}$ & 0.2 & & & 2.9 & 6.7 & 1.6 & & & & 7.1 & 3.2 & & & & & & & & & & & & & & & \\
\hline Bolivina pulchella & 0.7 & & & & & & 0.7 & & & & & 1.4 & & 0.3 & & 0.3 & & & & 0.4 & & & & & & \\
\hline Bolivina sp. & & & 1.5 & & & & & & & 0.5 & & & & & & 1.0 & & & & & & & & & & \\
\hline Bolivina striatula & 2.9 & 8.3 & 11.2 & 9.5 & 5.0 & 7.1 & 6.5 & 10.5 & 15.6 & 5.7 & & 9.9 & 10.0 & 3.4 & 7.61 & 11.97 & 7.5 & 13.7 & & 7.62 & 2.2 & 4.5 & & & & \\
\hline Buccella frigida & & & & & & & & 0.2 & & & & & & & & & & & & & & & & & & \\
\hline Buccella sp. & 0.7 & & & 2.9 & & 0.6 & & & & & & & & & & & & & & & & & & & & \\
\hline Bulimina elongata & 1.4 & & & & & 4.2 & 13.0 & 9.1 & 15.6 & 1.9 & 10.5 & & 7.6 & 4.4 & 26.81 & $11.2 \varepsilon$ & 8.8 & 4.9 & 1.22 & 20.92 & 2.2 & 0.3 & & 4.1 & & 2.6 \\
\hline Bulimina marginata & 1.0 & 4.2 & & 2.9 & 10.0 & 0.6 & & 2.6 & 2.1 & 6.6 & 7.3 & 9.9 & 1.0 & 1.7 & 1.7 & $8.3 \varepsilon$ & 8.8 & 7.8 & & & 3.3 & & & & & \\
\hline Bulimina sp. & 0.5 & & & & & & & 0.9 & & & & 1.4 & & & & & & & & & & & & & & \\
\hline $\begin{array}{c}\text { Buliminella } \\
\text { elegantissima }\end{array}$ & 0.2 & 4.2 & 2.2 & 2.9 & 13.31 & 16.2 & 41.0 & 21.7 & 17.3 & 14.2 & & 19.7 & 14.1 & 16.3 & 10.21 & 14.41 & 15.4 & 9.6 & 4.21 & 17.3 & 4.1 & 13.7 & 4.2 & 0.7 & 0.6 & 0.7 \\
\hline Cassidulina sp. & & & & & & & & & & & & & & & & 0.3 & & 4.7 & & & 0.8 & & & & & \\
\hline $\begin{array}{l}\text { Cassidulina } \\
\text { subglobosa }\end{array}$ & 15.52 & 20.8 & 21.6 & 26.7 & 5.0 & 8.4 & 0.7 & & 3.7 & 15.2 & 8.1 & 9.9 & 3.8 & 3.4 & 2.8 & 4.27 & 7.5 & & 0.2 & & & & & & & 1.3 \\
\hline Cibicides sp. & & & & & & & & & & & & & & & & & & & 1.2 & & 0.3 & & & & & \\
\hline Cibicides variabilis & & & & & 13.3 & 0.3 & & & & & & & & & & & & & & & & & & & & \\
\hline Cornuspira involvens & 0.2 & & 0.7 & & & & & & & & 0.8 & & & & & & & & & & & & & & & \\
\hline Discorbis sp. & 30.23 & 33.3 & 2.2 & 15.2 & & 2.6 & 0.3 & 0.2 & 0.4 & 1.4 & & & & & 0.2 & 0.6 & & & & & & & & & & \\
\hline Discorbis williamsoni & 11.7 & & 12.7 & 8.6 & 16.7 & 0.3 & & 0.2 & & 0.5 & & & & & & & & & & & & & & & & \\
\hline Elphidium discoidale & & & & & & & & & & & & & & & & & & & & 0.4 & & & & & & \\
\hline Elphidium excavatum & 0.2 & & & & & 0.6 & & & & & & & & & & & & & & & & 0.3 & & 0.7 & 1.2 & 22.4 \\
\hline Elphidium gunteri & & & & & & & & & & & & & & 0.3 & & & & & 2.3 & & & & & & & \\
\hline Elphidium poyeanum & & & 0.7 & & & 4.2 & & 0.2 & & & & & & & & & & & 2.8 & 0.8 & 4.6 & 3.01 & 14.03 & 39.31 & 15.4 & 5.3 \\
\hline Elphidium sp. & 0.2 & & & 1.9 & 3.3 & 1.0 & 0.7 & 0.5 & & & & & 0.3 & & & & & & & & & & & & & \\
\hline $\begin{array}{c}\text { Eponides } \\
\text { ciborrepandus }\end{array}$ & 0.7 & & & 1.0 & & & & & & & & & & & & & & & & & & & & & & \\
\hline Fissurina laevigata & & & & & & 1.0 & 0.7 & 0.5 & 6.6 & 1.4 & & & 2.4 & 2.0 & 2.6 & 1.3 & 0.9 & 0.6 & 0.2 & & & & & & & 2.0 \\
\hline Fursenkoina pontoni & & & & & & 0.6 & 0.7 & 3.5 & 0.8 & 1.4 & 0.8 & & 0.7 & & & 1.9 & & & & 0.8 & & & & 0.7 & & \\
\hline Gaudriyna exillis & 0.7 & & & 1.0 & & 6.8 & 2.0 & 0.9 & 2.1 & 9.5 & 9.7 & & 7.9 & 0.3 & & 1.0 & & & & & & & & & & \\
\hline Gaudriyna sp. & & & & & & & & & & & & & & & & 0.3 & & & & & & & & & & \\
\hline Globigerina sp. & & & & & & & & & & & 7.3 & & & & & 0.3 & & & & & & & & & & \\
\hline Haynesina germanica & 0.2 & & & & & & & & 0.8 & & & & & & & $0.3 c$ & 0.4 & & 0.2 & & 0.3 & & & & 0.6 & \\
\hline Hopkisina pacifica & & & & & & & 0.3 & & & & 0.8 & 1.4 & 2.1 & & 1.4 & & & & & & & & & & & \\
\hline Jovens & 1.9 & & & 6.7 & 3.3 & & & & & 3.8 & & & & 0.7 & 1.9 & & 1.3 & & & & & & & & 6.8 & 19.1 \\
\hline
\end{tabular}




\section{Continued}

$\begin{array}{cc}\begin{array}{c}\text { Millioninela } \\ \text { subrrotunda }\end{array} & 1.2 \\ \text { Pararotalia sp. } & 5.0\end{array}$

$3.8 \quad 1.7 \quad 1.6$

$1.4 \quad 1.0$

Pseudoclavulina curta

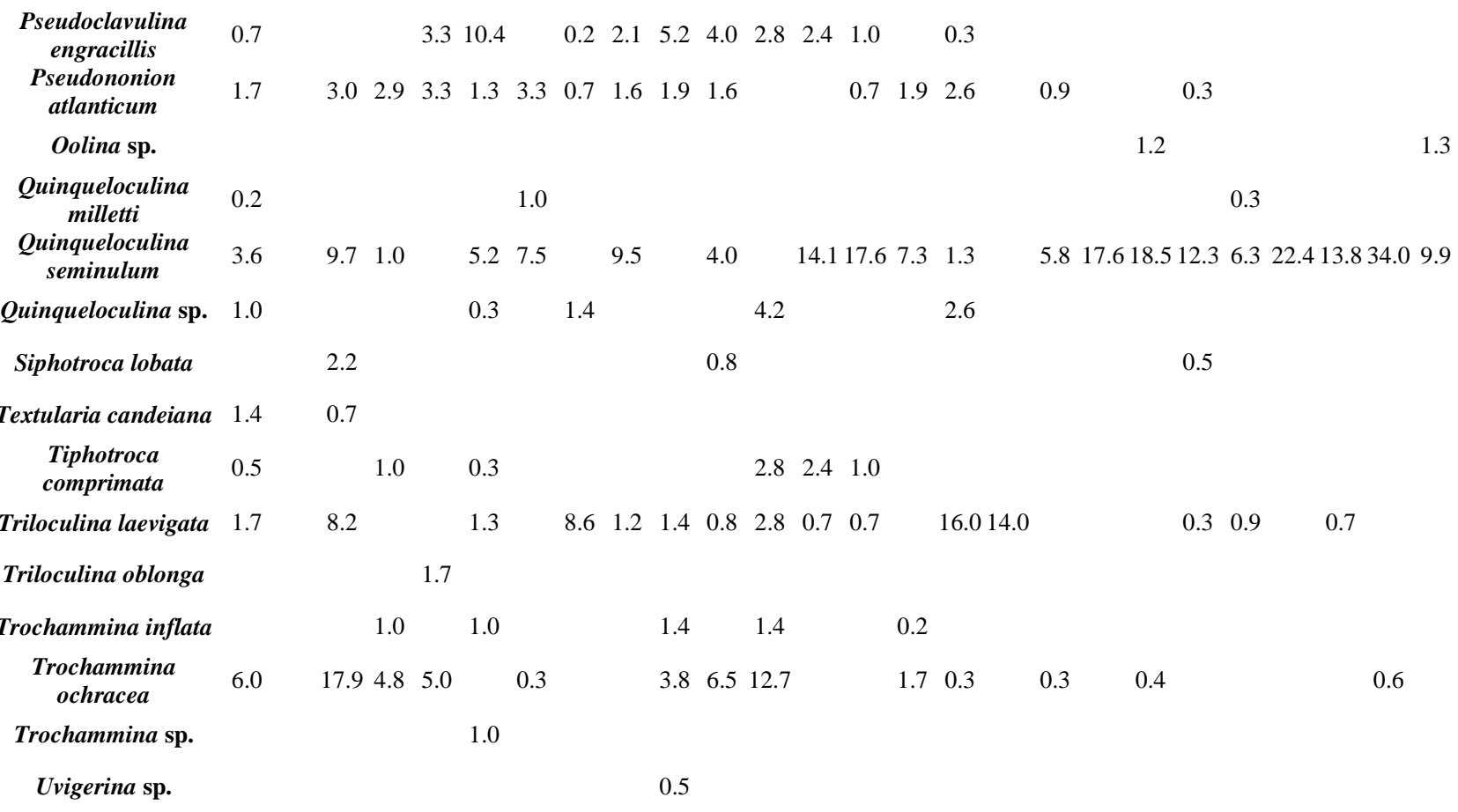

Table 3. Relative frequency of species distribution in Guanabara Bay (summer).

\begin{tabular}{|c|c|c|c|c|c|c|c|c|c|c|c|c|c|c|c|c|c|c|c|c|c|c|c|c|c|}
\hline SUMMER & 1 & 2 & 3 & 4 & 5 & 6 & 7 & 8 & 9 & 10 & 11 & 12 & 13 & 14 & 15 & 16 & 17 & 18 & 19 & 20 & 21 & 22 & 23 & 24 & 25 \\
\hline Ammobaculites sp. & & & & & & & 1.9 & & & & & & & & & & & & & & & & & & \\
\hline Ammonia roushalsenii & & & & & & & & & 0.1 & & & & & & & & & & & & & & & & \\
\hline Ammonia tepida & 25.0 & 40.9 & 5.0 & 3.9 & 8.2 & 5.6 & 24.4 & 23.4 & 25.3 & 31.1 & 15.0 & 8.9 & 26.5 & 40.0 & 38.4 & 41.1 & 13.3 & & 67.3 & 60.1 & 65.2 & 73.9 & 40.0 & 23.3 & 16.5 \\
\hline Ammotium salsum & & & & & & & & & & & & 2.2 & & & & & & & & & & & & & \\
\hline Amphistegina scalaris & & & & & & 0.3 & & & & & 1.7 & & & & & & & & & & & & & & \\
\hline Bolivina sp. & & & & & & & & & & & & & & & & & & 3.4 & & & & & & & \\
\hline Bolivina pulchella & & & & 0.3 & & & 1.0 & & 0.1 & 0.2 & & & & & & & & & & & & & & & \\
\hline Buccella sp. & & & 1.7 & & & 0.7 & & & & & & & & & & 0.5 & & & & 0.7 & & & & & \\
\hline Bulimina elongata & & 7.2 & & 1.1 & 0.9 & 0.7 & 2.9 & 14.6 & 10.1 & 5.9 & & 2.2 & 3.0 & & 5.7 & 9.6 & 3.9 & & 0.1 & 0.4 & 1.4 & & & & \\
\hline Bulimina marginata & 1.6 & 4.1 & & 1.7 & & 1.0 & 1.2 & 4.5 & 7.2 & 5.0 & 23.3 & 4.4 & 15.7 & & 4.1 & 2.9 & 3.6 & & 0.2 & 0.4 & & & & & \\
\hline Bulimina patagonica & & & & & & 2.0 & & & & & & & & & & & & & & & & & & & \\
\hline $\begin{array}{c}\text { Buliminella } \\
\text { elegantissima }\end{array}$ & & 10.1 & 0.8 & 4.2 & 3.6 & 2.3 & 16.7 & 19.5 & 16.3 & 14.2 & 7.5 & 14.4 & 13.9 & 18.3 & 27.5 & 19.1 & 51.2 & 10.3 & 5.7 & 4.9 & 1.4 & 0.9 & 5.6 & 1.7 & 0.6 \\
\hline Cassidulina subglobosa & 15.6 & 4.7 & 2.5 & 4.2 & 17.32 & 28.0 & 8.1 & 3.9 & 8.1 & 1.5 & 6.7 & & 1.8 & 0.9 & 1.1 & 2.9 & 6.0 & 6.9 & & 0.4 & & 0.3 & & & \\
\hline
\end{tabular}




\section{Continued}

\begin{tabular}{|c|c|c|c|c|c|c|c|c|c|c|c|c|c|c|c|c|c|c|c|c|}
\hline Cornuspira involvens & & & & 0.6 & 3.6 & & & & 0.1 & 0.2 & & & & & & & & & & \\
\hline Discorbis sp. & 6.3 & 0.9 & 9.2 & 5.6 & 10.0 & 5.6 & 4.8 & 0.6 & 0.8 & 1.1 & 4.2 & & 0.6 & & 0.3 & 1.4 & 0.9 & & 0.3 & 1.7 \\
\hline Discorbis williamsoni & 10.9 & 0.6 & 6.7 & 11.0 & 7.3 & 10.8 & 3.3 & & 0.6 & & 2.5 & & & & & 0.5 & & & 0.1 & \\
\hline Elphidium ssp. & 7.8 & 1.6 & 0.8 & 0.6 & 1.8 & 0.3 & 2.9 & 0.3 & & 5.0 & 1.7 & 5.6 & & & 4.3 & 0.5 & 0.3 & & 9.214 .917 .417 .827 .8 & 55.267 .5 \\
\hline Eponides cibrorrepandus & & & 0.8 & 0.8 & 0.9 & 1.3 & & & & & & & & & & & & & & \\
\hline Fissurina laevigata & & 1.9 & & 0.3 & 0.9 & 0.7 & 1.0 & 0.6 & 1.3 & 2.4 & & 4.4 & 3.0 & 2.6 & 0.5 & 1.4 & 1.5 & 3.4 & & \\
\hline Fursenkoina pontoni & & 0.9 & & & 0.9 & & 0.5 & 3.2 & 1.3 & 1.4 & & & 0.6 & & & 0.5 & 0.3 & & & \\
\hline Gaudryina exilis & & 0.3 & 1.7 & & 0.9 & 1.0 & 3.3 & & 0.2 & 1.1 & 3.3 & 3.3 & 3.6 & & & & & & & \\
\hline Globigerina sp. & & 0.3 & 14.2 & 0.3 & 0.9 & 1.0 & 0.5 & 0.6 & 0.3 & 0.8 & & & & & & & 0.9 & & 0.1 & \\
\hline Hanzawaia boucana & & & & & & 0.3 & & & & & & & & & & & & & & \\
\hline Haynesina germanica & & 1.3 & & 0.8 & 0.9 & 1.6 & 0.5 & 1.0 & 0.6 & 0.5 & 2.5 & & & 0.9 & 0.6 & & & & 0.4 & \\
\hline Lagena sp. & & & & & & & 0.5 & & & & & & & & & & & & & \\
\hline Lagena laevis & & & & & & 0.3 & 0.5 & & & & & & & & & & & & & \\
\hline Lagena stricta & & & & & & 0.3 & & & & & & & & & & & & & & \\
\hline Lenticulina sp. & & & 0.8 & & & 0.3 & & & & & 0.8 & & & & & 0.5 & & 3.4 & & 0.6 \\
\hline Lagena striatula & & & & & & & & & & & & 1.1 & & & & & & & & \\
\hline Monalisidium sollasi & & & & & & & & & & & 0.8 & & & & & & & & & \\
\hline Oolina sp. & & 0.6 & & & & 0.3 & & & & & & 7.8 & & & & & & & & 2.6 \\
\hline
\end{tabular}

Oolina striatula

0.1

Orthomorphina filiformis

Pararotalia sp. $\quad 3.1$

Pseudoclavulina curta

Pseudononion atlanticum

Quinqueloculina sp. 4.7

Quinqueloculina

Iamarkiana

Quinqueloculina seminulum

Textularia sp.

Textularia candeiana

Textularia gramen

Throchammina inflata

$\begin{array}{llllllllllll}3.6 & 3.0 & 6.2 & 3.6 & 1.7 & 1.7 & 4.2 & 14.4 & 4.2 & 27.0 & 4.1\end{array}$

$0.672 .414 .412 .714 .5 \quad 3.625 .612 .912 .8$ 0.8

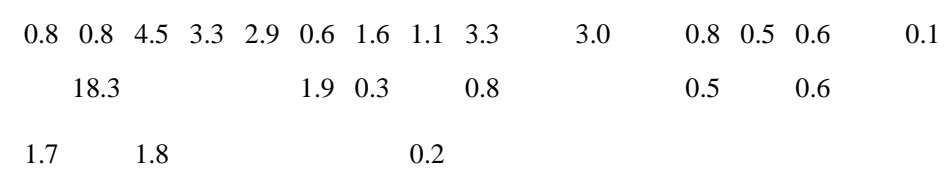

1.0

0.8

$\begin{array}{llll}2.5 & 1.1 & 0.9 & 0.5\end{array}$

$\begin{array}{lllllllllllll}\text { Throchammina ochracea } 12.5 & 20.8 & 1.4 & 1.6 & 1.0 & 0.3 & 0.3 & 0.2 & 5.8 & 15.6 & 7.2 & 1.7 & 0.3\end{array}$

Throchammina plana
discorbis

Tiphotroca comprimata 4.7

$\begin{array}{lllll}0.8 & 0.3 & 6.4 & 5.6 & 2.4\end{array}$

$0.2 \quad 2.510 .07 .2$

$0.1 \quad 0.8$

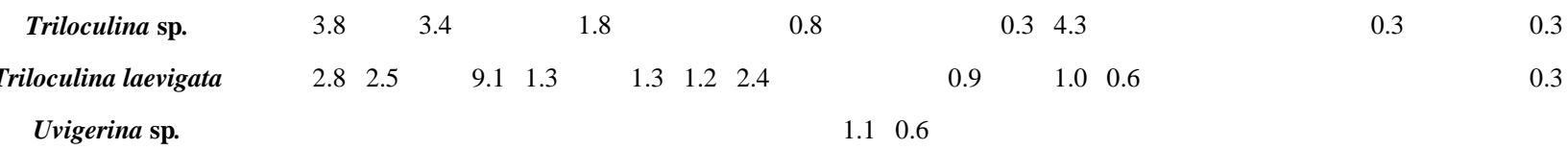

Uvigerina peregrina

2.5

Jovem

0.9

10.2

$0.3 \quad 5.0$

$1.8 \quad 1.1$

$\begin{array}{ll}1.7 & 0.7\end{array}$

$\begin{array}{lll}0.9 & 2.6 & 0.9\end{array}$ 


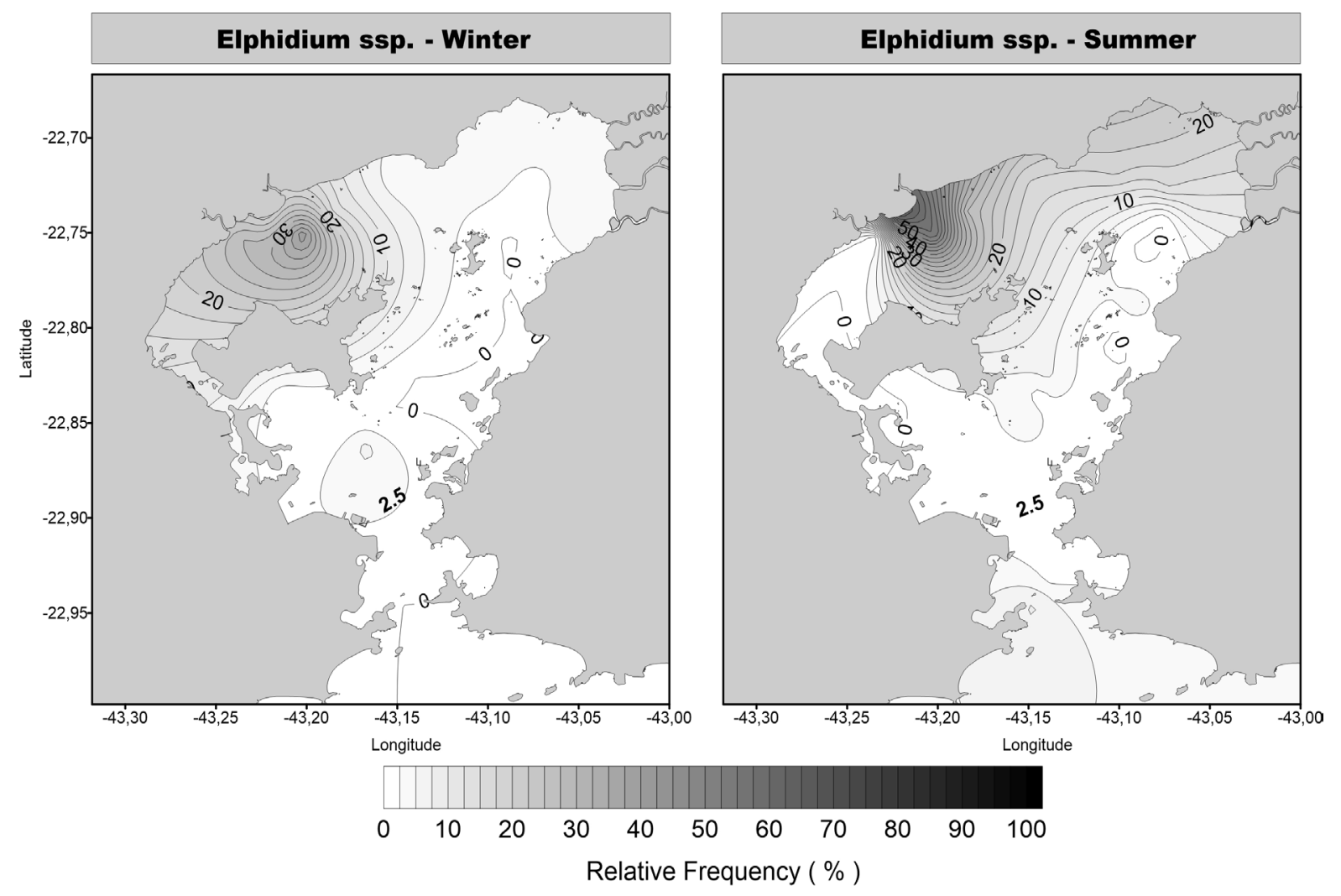

Figure 6. Distribution of the relative frequency of Elphidium spp.

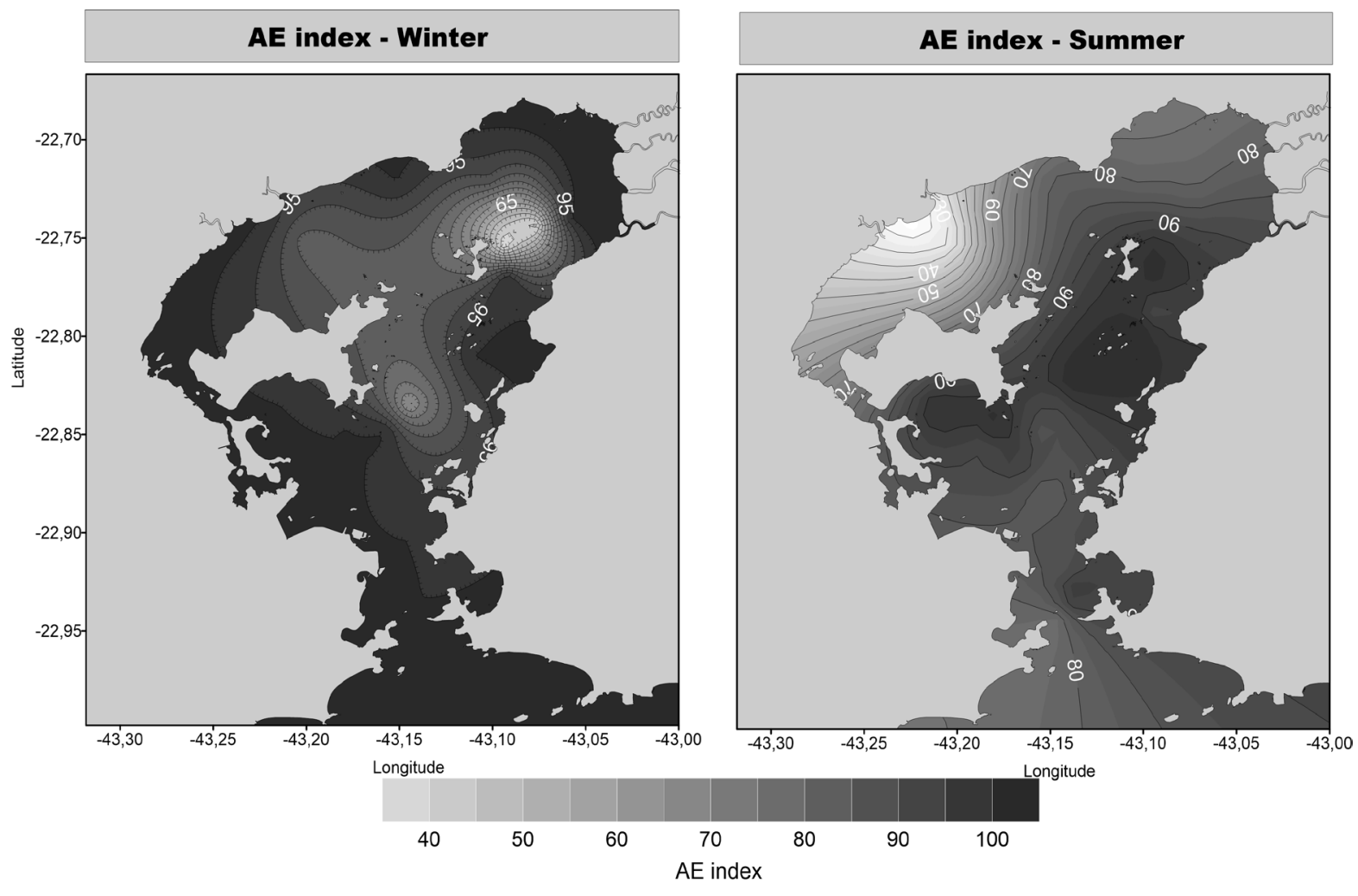

Figure 7. AE index for the samples collected in the winter and summer. 


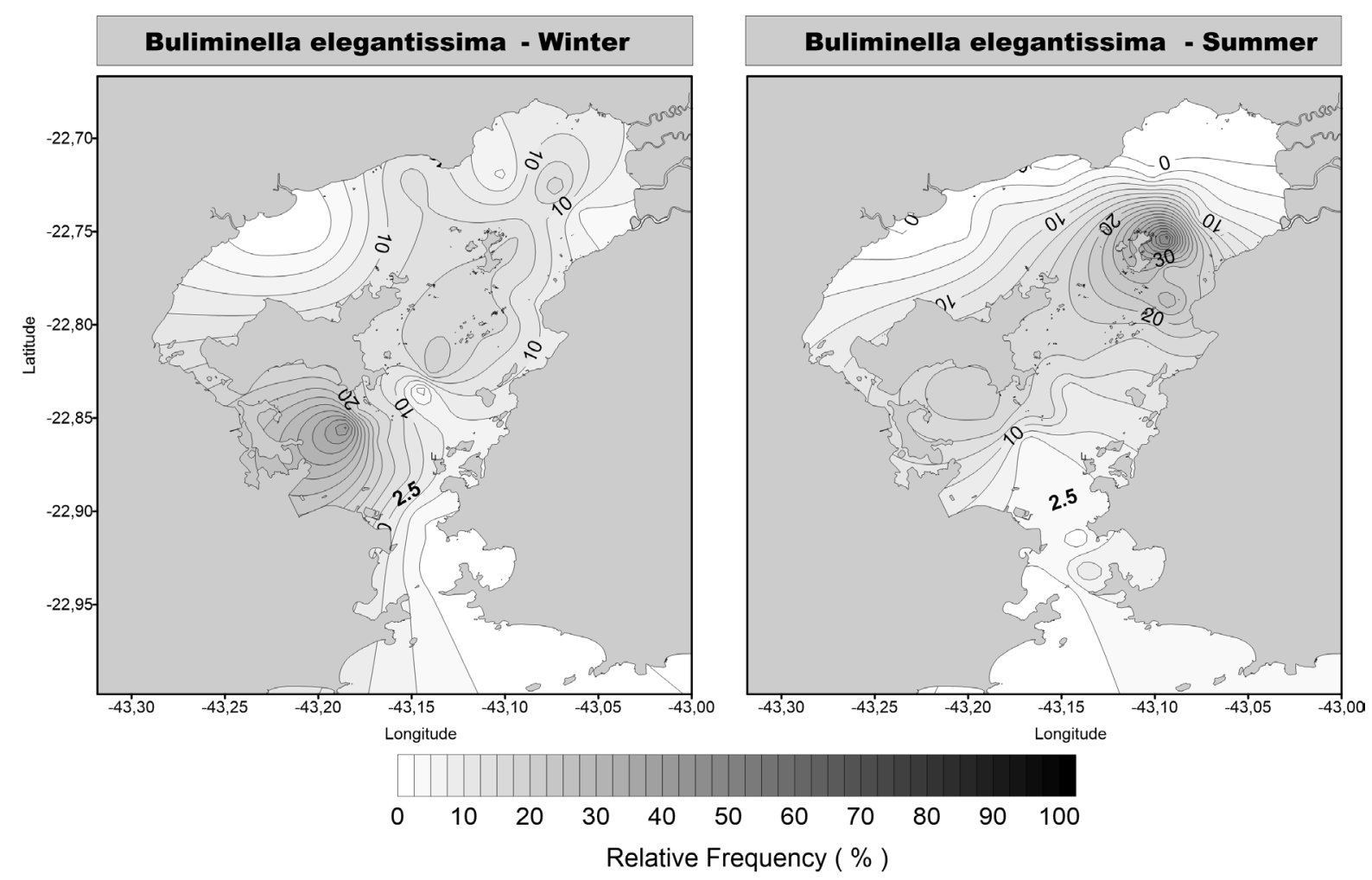

Figure 8. Distribution of the relative frequency of Buliminella elegantissima.

Table 4. Values for AE Index for the samples collected in the winter and summer.

\begin{tabular}{ccc}
\hline AE Index & Winter/2000 & Summer/2001 \\
\hline $\mathbf{1}$ & 0.00 & 76.19 \\
$\mathbf{2}$ & 0.00 & 96.30 \\
$\mathbf{3}$ & 0.00 & 85.71 \\
$\mathbf{4}$ & 0.00 & 87.50 \\
$\mathbf{5}$ & 1.22 & 81.82 \\
$\mathbf{6}$ & 0.03 & 94.44 \\
$\mathbf{7}$ & 0.00 & 89.47 \\
$\mathbf{8}$ & 0.00 & 98.63 \\
$\mathbf{9}$ & 0.00 & 100.00 \\
$\mathbf{1 0}$ & 0.00 & 86.19 \\
$\mathbf{1 1}$ & 37.21 & 90.00 \\
$\mathbf{1 2}$ & 23.53 & 100.00 \\
$\mathbf{1 3}$ & 0.00 & 100.00 \\
$\mathbf{1 4}$ & 0.75 & 100.00 \\
$\mathbf{1 5}$ & 1.40 & 89.93 \\
$\mathbf{1 6}$ & 0.00 & 98.85 \\
\hline & & \\
\hline
\end{tabular}




\begin{tabular}{cccc} 
Continued & & & \\
\hline $\mathbf{1 7}$ & 10.67 & 97.78 \\
$\mathbf{1 8}$ & 10.30 & 0.00 \\
$\mathbf{1 9}$ & 0.00 & 87.97 \\
$\mathbf{2 0}$ & 17.02 & 80.10 \\
$\mathbf{2 1}$ & 11.27 & 78.95 \\
$\mathbf{2 2}$ & 0.00 & 80.58 \\
$\mathbf{2 3}$ & 8.25 & 59.02 \\
$\mathbf{2 4}$ & 11.43 & 29.67 \\
$\mathbf{2 6}$ & 0.00 & 19.66 \\
\hline
\end{tabular}

\subsection{Foraminifera Indicator Species}

Buliminella elegantissima is also typical of environments with low oxygen and high concentration of organic matter and was present in abundance stations in winter, at stations 6 to 10 (south of Ilha do Governador) and in summer, at stations 13 and 14 (the central part of the Bay) in the anoxic zone (Figure 8). B. elegantissima dominates anoxic regions, near São J. do Meriti River, south of Ilha do Governador and the central region. However, in the anoxic station 26, near REDUC, this species is absent due to the fragility of its thin test that does not tolerate low $\mathrm{pH}$.

\section{Discussion}

In general, the distribution of foraminifera found in Guanabara Bay in winter and summer is similar, consisting mainly of opportunistic species - tolerant, and low diversity with a strong dominance of a few species.

The species of benthic foraminifera, present in micro-geographical features which are highly controlled by environmental factors in different environments, can be established. In spite of the major factors controlling the establishment of species being changes in salinity and temperature [11] [12] [17], in Guanabara Bay, the change in $\mathrm{pH}$ and oxygen concentration also plays an important role in controlling the establishment of foraminiferal species.

\subsection{Ecological Accident}

The low pH, derived from the oil spill, caused a relative increase of specimens of Elphidium spp. in winter (6 months after the accident in January 2000). It is believed that this relative increase is mainly due to the absence of other species with thinner shells that were quickly dissolved. Next to REDUC, the acidity of the sediment suggests that the dissolution of carbonates in the region, culminated in the complete sterility of the sample one year after the accident (station 26, single station sterile). For example, B. elegantissima was found in the area of environmental preservation (APA Guapimirim) in winter, but not close to REDUC, indicating that this species does not tolerate acidic $\mathrm{pH}$ environments, given the fragility of its thin shell. The damage assessment 6 months and 1 year after the accident was interesting since it was still evident through mortality and other symptoms in the population for more than one year.

\subsection{Domestic Sewage}

It is noteworthy that the oil spill reached an already stressed and altered ecosystem since the Guanabara Bay is highly urbanized. The dumping of sewage from the city of Rio de Janeiro takes place mainly in the waters of the Rio S. J. Meriti located west of the Ilha do Governador. Our results show that the south of Ilha do Governador is seriously compromised because low efficiency of water renewal is unable to export the pollutants from the São J. do Meriti River.

According to [9], the west margin and the inner parts of the bay show high concentrations of nutrients (nitro- 
gen, phosphate and sulfur) due to the enrichment from domestic discharge and low efficiency in the renewal of the waters near Ilha do Governador and Ilha do Fundão. Our study indicated these locations as seriously impacted because the São J. do Meriti River influences the environments also at the north of the bay. This happens because in the west of the Ilha do Governador, which would be the "natural" way of water flow, is stagnated and closed due to silting and littering in the region. Consequently, the passage of water tends to occur to the north, preventing renewal of waters.

Most of the bays are characterized by high concentration of oxygen in the sediment, which enables the maintenance of high biological activity [18]. However, large amounts of waste of organic material (sewage) can create areas where oxygen consumption exceeds supply, especially during the summer months, making the anoxic environment, precisely what was observed in this study to the south of the Ilha do Governador. The central region of the Bay has the lowest background concentration of oxygen. This fact is also related to the increase in temperature this time of year and the "bloom" of phytoplankton, which results in a greater area of eutrophication and consequent hypoxia. The study of seasonality in the Bay shows seasonal periods of hypoxia similar to those observed in coastal areas: Chesapeake Bay [19], Gulf of Mexico [20], and the Continental Shelf of Louisiana [14].

In an assessment of cellular stress in mollusks, [21] observed that animals from the south of Ilha do Governador were more clearly affected by local pollution. Our study clearly reflects the loss of biological communities in relation to the rest of the Bay and the south of Ilha do Governador requires further attention since they are regions where there is a high organic dump across the S. J. do Meriti River. Our results also agree with [22], who observed that the concentration of ammonia, chlorophyll and turbidity observed in regions close to the Ilha do Governador and Ilha do Fundão are high relative to the rest of the Bay, and far above the standard set by CONAMA (National Environmental Council), evidencing the process of degradation in the Bay.

The influence of contamination (sewage) on the population of foraminifera has been widely studied and a thorough review is cited in [23]. In Guanabara Bay, benthic foraminifera have been looked at by [24]-[26] as bioindicators in the determination of human impacts in coastal and paralic environments as well as in the Rodrigo de Freitas Lagoon, RJ [27]. In the inner continental shelf of southern Brazil, in Laguna [28] foraminifera benthic fauna has undergone degradation in the central sector, because the accumulation of sand and the absence of fine material here are conducive to the development of a barren zone. Populations of coliform bacteria, however, exist all over; and their development does not seem to be related to the amount of silt and clay in the sediment. The accumulation of silt and clay in Laguna [28] and in the present study is linked to both a "natural" source, influenced by the river run off, and an anthropogenic source, i.e., the sewage outfall.

A study done at the Olaria River (Cananéia, SP), by [29] found that organic pollution mainly associated with regular renewal of the water on each tide, favored the establishment of opportunistic species; the same could be observed in Guanabara Bay.

The analysis of the levels of hypoxia, through the AE index, suggests that Guanabara Bay is a highly anthropogenic altered environment on the margins, reaching their maximum values in these regions. It is known that this index considers the genera Ammonia and Elphidium as indicators of pollution levels, Ammonia as an indicator of polluted environments, and Elphidium characterized as less tolerant to pollution [14]. This hypothesis was corroborated by [30] in Guanabara Bay and by Pereira [31] in Cananéia and Santos estuarine systems, where both authors observed that Ammonia tepida was resistant to low concentration of dissolved oxygen (anoxic environment) and high sulfur values characteristic of toxic sediments. Larger population of A. tepida relates to the reduction of dissolved oxygen concentration in the bottom sediments (related to $3 \mathrm{mg} / \mathrm{l}$, [32]), while smaller populations are found where the $\mathrm{pH}$ is acidic [33].

Our study revealed that $B$. elegantissima is more abundant in the anoxic regions south of Ilha do Governador and central bay. This finding reinforces that B. elegantissima is typical of organic matter enriched sediments, with low oxygen, occurring in sediments contaminated by domestic sewage [14] [29] [34], and that excessive nutrient enrichment favors the proliferation of opportunistic foraminiferal species with high growth rates, increasing the local dominance [11].

Environments with high organic matter concentration are directly related to higher concentrations of fine sediment [35]. This type of sediment is characteristic of low energy environment which facilitates the organic matter deposition. Moreover, in these regions, the oxygen concentration is very low. Note that B. elegantissima presented its highest relative frequency exactly where hypoxia is enhanced in the region south of Ilha do Governador in winter and in the central region near the anoxic zone in the summer. Anoxic zones are usually lo- 
cated where the increase of bacteria from extreme concentrations of pollutants decreases oxygen concentration [36].

The hypoxic region of REDUC suggests that this environment, although its oxygen concentration is similar to the APA, has greater limitation in productivity, compared to the preserved region. The dominance index values are high both in the region closer to REDUC and in the central part, anoxic zones, reflecting the establishment of a few species adapted to those polluted and contaminated conditions.

Our study indicates that Guanabara Bay is highly impacted, reflecting a low diversity of fauna, dominated by a few species. The number of species per sample increases when environmental conditions are more typically saline. Therefore, one would expect that if compared to other less saline lagoons and estuaries in Brazil, for example, the Estuarine Lagoon System Cananéia-Iguape, SP [29] [37], Bertioga Channel, SP [11] [38] [39], the estuaries of Estação Ecológica Juréia-Itatins, SP [40], Lagoa da Conceição, SC [41], Guanabara Bay would have more foraminiferal species.

\section{Conclusions}

It was observed that tolerant opportunistic species (Ammonia tepida and Buliminella elegantissima) benefit directly from organic contamination increasing their relative abundance. The other type of benefit may be indirect, as occurred for Elphidium spp., which greatly increases its dominance due to the absence of other species that have had their shells dissolved first, resulting from the primary impact of the oil spills.

This work showed the applicability in the use of population dynamics of foraminifera correlated with abiotic parameters to provide data in environmental quality and coastal management plans. In this sense, it was possible to see the location of the region most subject to pollution and contamination and to identify pollution sources.

The results to date reaffirm the use of foraminiferal species in studies of pollution by oil and sewage, even where the dissolution of carbonate is active due to low $\mathrm{pH}$ values.

We conclude that pollution or contamination of an environment overlaps the natural environmental factors, therefore limiting the establishment of species that are not opportunistic.

\section{Acknowledgements}

The field and laboratory work was financially supported by the Fundação de Amparo à Pesquisa do Estado de São Paulo (FAPESP 99/10678-5) and the Oceanographic Institute of São Paulo University (IOUSP). Special thanks are owed to the crew members of Véliger Oceanographic Vessel for help with the fieldwork. This work received an improvement grant supported by the Inter American Institute, through South Atlantic Climate Change (SACC/CRN-061 project). The first author is deeply thankful to Dr. Helenice Vital and CAPES through the Edital Ciências do Mar 207/2010 for the Post Doc Fellowship at the Laboratório de Geologia e Geofísica Marinha e Monitoramento Ambiental da Universidade Federal do Rio Grande do Norte (GGEMMA-UFRNBrazil) providing means for this research to be published.

\section{References}

[1] Woo, H.J., Culver, S.J. and Oertel, G.F. (1997) Benthic Foraminiferal Communities of a Barrier-Lagoon System, Virginia, USA. Journal of Coastal Research, 13, 1192-1200. http://www.jstor.org/stable/4298728

[2] Sen-Gupta, B. (1999) Modern Foraminifera. Kluver Academic Publishers, Dordrecht, 371 p.

[3] Oberhansli, H. (1992) Planktonic Foraminifers as Tracers of Ocean Currents in the Eastern. South Atlantic. Paleoceanography, 7, 607-632. http://dx.doi.org/10.1029/92PA01236

[4] Boltovskoy, E. and Wright, R. (1976) Recent Foraminifera. Junk, The Hague, 515 p. http://dx.doi.org/10.1007/978-94-017-2860-7

[5] Scott, D.B., Schafer, C.T., Honig, C. and Younger, D.C. (1995) Temporal Variations of Benthic Foraminiferal Assemblages under or near Aquaculture Operations: Documentation of Impact History. Journal of Foraminiferal Research, 25, 224-235. http://dx.doi.org/10.2113/gsjfr.25.3.224

[6] Kennish, M.J. (1997) Practical Handbook of Estuarine and Marine Pollution. Marine Science Series, Boca Raton.

[7] Amador, E.S. (1997) Baía de Guanabara e Ecossistemas Periféricos: Homem e Natureza. E. S. Amador, Rio de Janeiro.

[8] Catanzaro, L.F., Baptista Neto, J.A., Guimaraes, M.S.D. and Silva, C.G. (2004) Distinctive Sedimentary Processes in Guanabara Bay—SE/Brazil, Based on the Analysis of Echo-Character (7.0 kHz). The Revista Brasileira de Geofísica, 
22, 69-83. http://dx.doi.org/10.1590/S0102-261X2004000100006

[9] Kjerfve, B., Ribeiro, C.H.A., Dias, G.T.M., Filippo, A.M. and Quaresma, V.S. (1997) Oceanographic Characteristics of an Impacted Coastal Bay: Baía de Guanabara, Rio de Janeiro, Brazil. Continental Shelf Research, 17, 1609-1643. http://dx.doi.org/10.1016/S0278-4343(97)00028-9

[10] Pritchard, D.W. (1967) What Is an Estuary: Physical Viewpoint. In Estuaries. AAAS, Washington DC.

[11] Eichler, B.B., Eichler, P.P.B., Miranda, L.B., Bérgamo, A.L., Bernardes, M.E.C., Pereira, E.R.M., Kfouri, P.B.P. and Pimenta, F.M. (2001) Utilização de foraminíferos como bioindicadores da influência marinha na Baía de Guanabara, (RJ, Brasil). Revista Pesquisas,28, 251-282.

[12] Eichler, P.P.B., Eichler, B.B., de Miranda, L.B., Pereira, E.R.M., Kfouri, P.B.P., Pimenta, F.M., Bérgamo, A.L. and Vilela, C.G. (2003) Benthic Foraminiferal Response to Variations in Temperature, Salinity, Dissolved Oxygen and Organic Carbon, in the Guanabara Bay, Rio de Janeiro, Brazil. Anuário do Instituto de Geociências, 26, 36-51.

[13] JICA (1994) The Study of Recuperation of the Guanabara Bay Ecosystem, 8 Volumes. Japan International Cooperation Agency, Kokusai Kogyo Co. Ltd., Tokyo.

[14] Sen-Gupta, B.K., Turner, R.E. and Rabalais, N.N. (1996) Seasonal Oxygen Depletion in Continental Shelf Waters of Louisiana: Historical Record of Benthic Foraminifers. Geology, 24, 227-230. http://dx.doi.org/10.1130/0091-7613(1996)024<0227:SODICS >2.3.CO;2

[15] Landim, P.M.B. (1997) Análise estatística de Dados Geológicos. Editora UNESP, São Paulo, 226 p.

[16] Brooks, G.R. and Doyle, L.J. (1998) Recent Sedimentary Development of Tampa Bay, Florida: A Microtidal Estuary Incised into Tertiary Carbonate Platform Carbonates, Estuaries, 21, 391-406. http://dx.doi.org/10.2307/1352838

[17] Eichler, P.P.B., Billups, K. and Velez, C.C. (2010) Investigating Faunal and Geochemical Methods for Tracing Salinity in an Atlantic Coastal Lagoon, Delaware, USA. Journal of Foraminiferal Research, 40, 14-33. http://dx.doi.org/10.2113/gsjfr.40.1.16

[18] Alve, E. (1995) Benthic Foraminiferal Responses to Estuarine Pollution: A Review. Journal of Paleontology, 25, 190204.

[19] Boesch, D.F. and Rabalais, N.N. (1991) Effects of Hypoxia on Continental Shelf Benthos: Comparisons between the New York Bight and the Northern Gulf of Mexico. In: Tyson, R.V. and Pearson, T.H., Eds., Modern and Ancient Continental Shelf Anoxia, The Geological Society, London, 27-34.

[20] Malone, T.C. (1991) River Flow, Phytoplancton Production and Oxygen Depletion in Chesapeak Bay. Geological Society, London, Special Publications, 58, 83-93. http://dx.doi.org/10.1144/GSL.SP.1991.058.01.06

[21] Cavalier, B.D., Amorim, M.A., Lima, E.F.A. and Wagener, A. (2000) O uso do ensaio lissossomal para avaliação para avaliação rápida de estresse celular em mexilhão Perna perna da Baía de Guanabara, RJ. Anais XIII Semana Nacional de Oceanografia, 1, 224-226.

[22] Amorim, M.A., Sabino, C. and Zee, D. (2001) Acompanhamento espaço-temporal da qualidade da água na Baía de Guanabara. In: XIII Semana Nacional de Oceanografia, 308-310.

[23] Armynot Du Châtelet, E., Debenay, J.P. and Soulard, R. (2004) Foraminiferal Proxies for Pollution Monitoring in Moderately Polluted Harbors. Environmental Pollution, 127, 27-40. http://dx.doi.org/10.1016/S0269-7491(03)00256-2

[24] Vilela, C.G., Sanjinés, A.E.S., Ghiselli Jr., R.O., Mendonça Filho, J.G., Baptista Neto, J.A. and Barbosa, C.F. (2003) Search for Bio Indicators of Pollution in the Guanabara Bay: Integrations of Ecologic Patterns. Anuário do Instituto de Geociências, 26, 25-35.

[25] Vilela, C.G., Batista, D.S., Baptista-Neto, J.A., Crapez, M. and Mcallister, J.J. (2004) Benthic Foraminifera Distribution in High Polluted Sediments from Niterói Harbor (Guanabara Bay), Rio de Janeiro, Brazil. Anais da Academia Brasileira de Ciências, 76, 161-171. http://dx.doi.org/10.1590/S0001-37652004000100014

[26] Vilela, C.G., Figueira, B.O. and Baptista Neto, J.A. (2007) Ecology and Paleoecology in Guanabara Bay, Rio de Janeiro, during the Last 6000 Years Based in Benthic Foraminifera Assemblage Variations. In: Carvalho, I.S., Cassab, R.C.T. and Schwanke, C., Eds., Paleontologia: cenários de vida, 2nd Edition, Interciência, Rio de Janeiro, 345-361.

[27] Vilela, C.G., Batista, D.S., Baptista Neto, J.A. and Ghiselli Jr., R.O. (2011) Benthic Foraminifera Distribution in a Tourist Lagoon in Rio de Janeiro, Brazil: A Response to Anthropogenic Impacts. Marine Pollution Bulletin, 62, 20552074. http://dx.doi.org/10.1016/j.marpolbul.2011.07.023

[28] Eichler, P.P.B., Eichler, B.B., Sen Gupta, B. and Rodrigues, A.R. (2012) Foraminifera as Indicators of Marine Pollutant Contamination on the Inner Continental Shelf of Southern Brazil. Marine Pollution Bulletin, 64, 22-30. http://dx.doi.org/10.1016/j.marpolbul.2011.10.032

[29] Eichler, B.B., Debenay, J.P., Bonetti, C. and Duleba, W. (1995) Répartition des Foraminifères benthiques dans la zone Sud-Ouest du Système laguno-estuarien d’Iguape-Cananéia (Brésil). Boletim do Instituto Oceanográfico, 43, 1-17. http://dx.doi.org/10.1590/S0373-55241995000100001 
[30] Kfouri, P.B.P. (2006) Análise tafonômica de testas de foraminíferos em sedimentos de sub-superfície e superfície da Baía de Guanabara (RJ-Brasil). Programa de Pós-Graduação em Oceanografia, Universidade de São Paulo, Instituto Oceanográfico, Tese de Doutorado, 133 p.

[31] Pereira, E.R.M. (2010) Aplicabilidade dos foraminíferos como organismos traçadores—Estudo aplicado em duas regiões estuarinas distintas: Os Sistemas de Santos e Cananéia-São Paulo (SP), Brasil. Thesis Doctoral, Instituto Oceanográfico, Universidade de São Paulo, São Paulo.

http://www.teses.usp.br/teses/disponiveis/21/21131/tde-03082011-163453/

[32] Seiglie, G.A. (1967) Systematic of the Foraminifera from Araya-Los Testigos Shelf and Upper Slope, Venezuela with Special Reference to Suborder Rotaliina and Its Distribution. Caribbean Journal of Science, 7, 95-133.

[33] Bradshaw, J.S. (1961) Laboratory Experiments on the Ecology of Foraminifera. Contributions from the Cushman Foundation for Foraminifera Research, 12, 87-106.

[34] Setty, A. and Nigam, R. (1982) Foraminiferal Assemblages \& Organic Carbon Relationship in Benthic Marine Ecosystem of Western Indian Continental Shelf. Indian Journal of Marine Sciences, 11, 225-232.

[35] Tyson, R.V. (1995) Sedimentary Organic Matter. Chapman \& Hall, London, 589 p. http://dx.doi.org/10.1007/978-94-011-0739-6

[36] Schafer, C.T., Collins, E.S. and Smith, J.N. (1991) Relationship of Foraminiufera and Thecamoebian Distributions to Sediments Contaminated by Pulp Mill Effluent. Saguenay Fjord, Quebec, Canadá. Marine Micropaleontology, 17, 255-283. http://dx.doi.org/10.1016/0377-8398(91)90016-Y

[37] Semensatto Jr., D.L., Funo, R.H.F., Dias-Brito, D. and Coelho Jr., C. (2009) Foraminiferal Ecological Zonation along a Brazilian Mangrove Transect: Diversity, Morphotypes and the Influence of Subaerial Exposure Time. Revue de Micropaléontologie, 52, 67-74. http://dx.doi.org/10.1016/j.revmic.2008.06.004

[38] Rodrigues, A.R. (2000) Resposta das associações de foraminíferos às variações ambientais ocorrentes no canal de Bertioga (SP). Monografia bacharelado, Universidade Metodista de São Paulo, São Paulo, 74 p.

[39] Eichler, P.P.B., Eichler, B.B., Miranda, L.B. and de Rodrigues, A.R. (2007) Modern Foraminiferal Facies in a Subtropical Estuarine Channel, Bertioga, Sao Paulo, Brazil. Journal of Foraminiferal Research, 37, 234-247. http://dx.doi.org/10.2113/gsjfr.37.3.234

[40] Duleba, W. and Debenay, J.P. (2003) Hydrodinamic Circulation in the Estuaries of Estação Ecológica Juréia-Itatins, Brazil, Inferred from Foraminifera and Thecamoebian Assemblages. Journal of Foraminiferal Research, 33, 62-93. http://dx.doi.org/10.2113/0330062

[41] Debenay, J.P., Eichler, B.B., Guillou, J.J., Eichler-Coelho, P., Coelho, C. and Porto-Filho, E. (1997) Comportement des peuplements de foraminifères et comparaison avec l'avifaune dans une lagune fortement stratifiée: la Lagoa da Conceição (S.C., Brésil). Revue de Paléobiologie, 16, 55-75. 
Scientific Research Publishing (SCIRP) is one of the largest Open Access journal publishers. It is currently publishing more than 200 open access, online, peer-reviewed journals covering a wide range of academic disciplines. SCIRP serves the worldwide academic communities and contributes to the progress and application of science with its publication.

Other selected journals from SCIRP are listed as below. Submit your manuscript to us via either submit@scirp.org or Online Submission Portal.
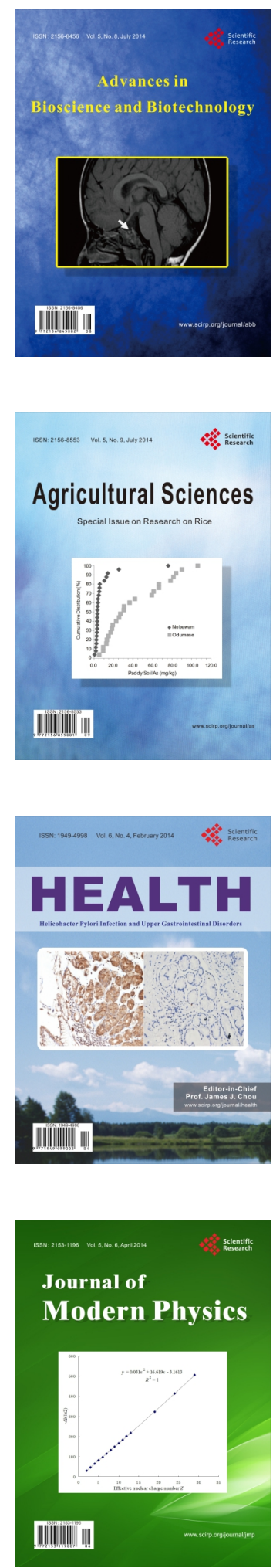
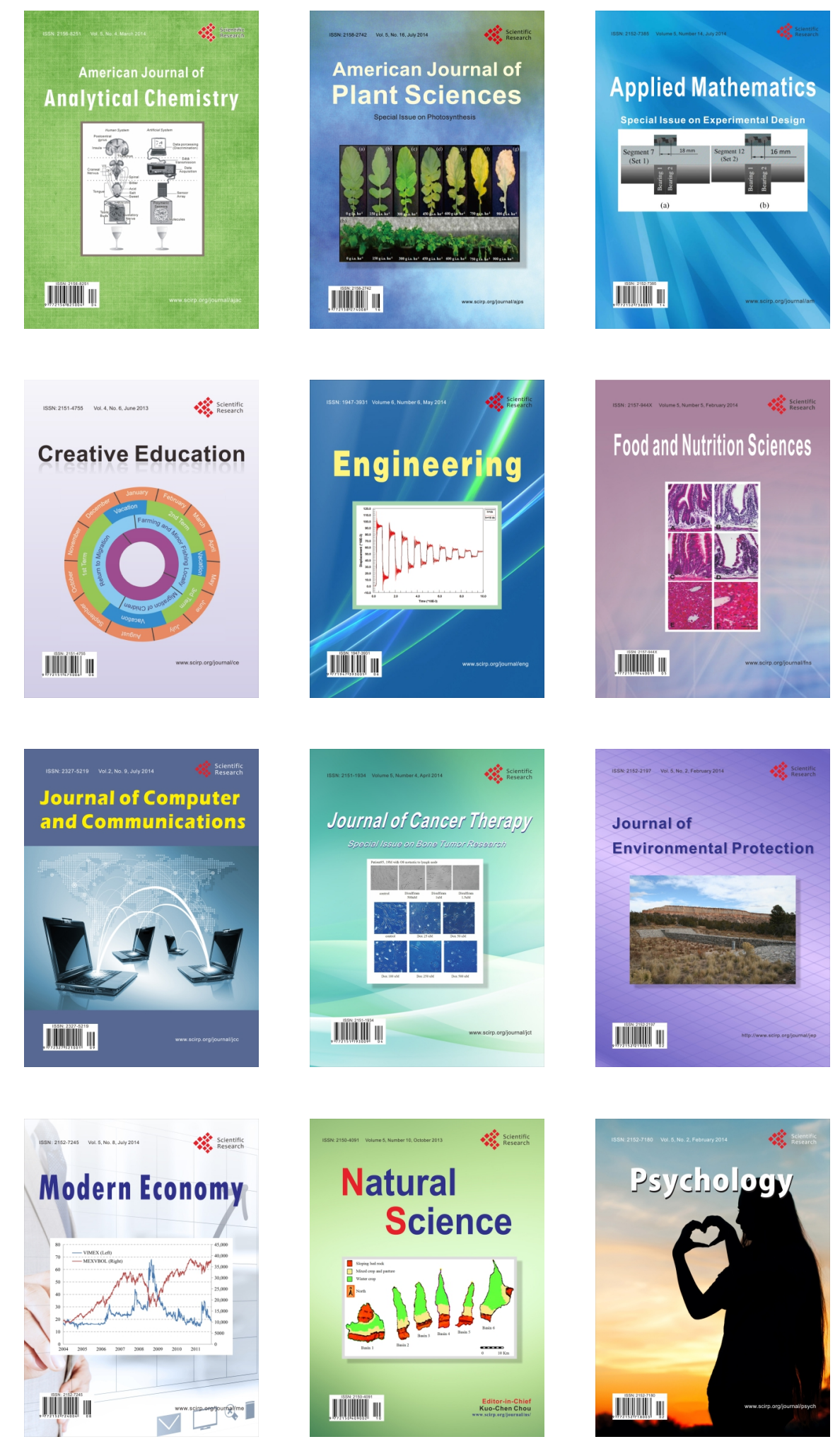